\title{
Constitutional Theories: A Taxonomy and (Implicit) Critique
}

\author{
LARRY ALEXANDER*
}

TABLE OF CONTENTS

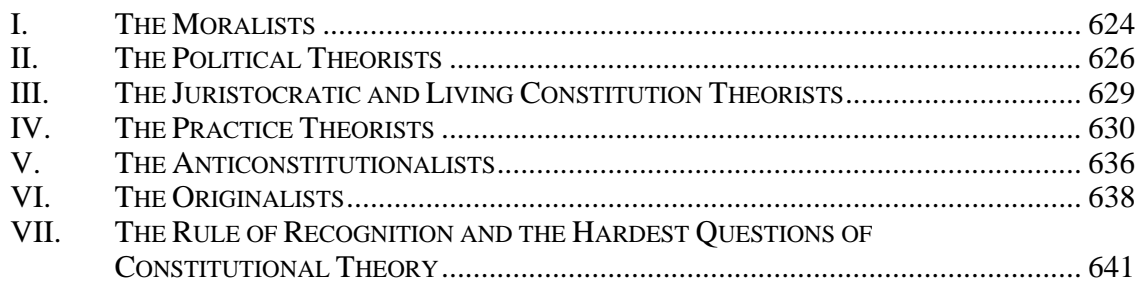

I am honored to have been invited to present this Madison Lecture, and I want to thank my hosts, Robby George and Brad Wilson, for their hospitality and for the excellence achieved by the Madison Program under their stewardship.

My charge was to present something on constitutional theory. Now, as you shall see, I do work in one corner of constitutional theory, and of course I believe it is the right corner to work in and that all constitutional theorists should be working in my corner. The baleful truth, however, is that most constitutional theorists reject that claim, despite several articles of mine urging them to do otherwise. So, to date, I have failed in my 
normative aspirations regarding constitutional theory, and this lecture will steer clear of preaching to the unconverted.

What I intend to do instead is to categorize the extant approaches to constitutional theory, including mine. I am going to taxonomize rather than criticize; although, I confess, some criticisms will seep through, albeit mainly implicitly.

\section{THE MORALISTS}

The first group of constitutional theorists I wish to discuss I label the "moralists." These theorists view the Constitution-at least large parts of it-and thus constitutional law as an invitation to implement their favorite moral theory as the law of the land. Some moralists claim that the Constitution itself, in phrases such as "due process of law" or "equal protection of the laws," invites judges to do moral theory and then impose that theory's strictures as constitutional law, supreme over all other law. ${ }^{1}$ Others view the point of the Constitution to be the legal implementation and protection of our preexisting moral rights. ${ }^{2}$ In their view, any attempted derogation from those rights would be a constitutional nullity regardless of the Constitution's specific text. ${ }^{3}$

Constitutional moralists come in all political shades. Some are on the left of the political spectrum. A generation ago, David A.J. Richards "found" in the Constitution a Rawlsian theory of justice. ${ }^{4}$ Somewhat earlier, in his famous Foreword to the Harvard Law Review, Frank Michelman argued that the Fourteenth Amendment could serve as the basis for a judicially ordered and Rawlsian-justified redistribution of wealth. $^{5}$ Much more recently, Larry Sager has postulated that the Constitution is incorrigible and is "justice-seeking," even if not all of the justice it seeks should be implemented by judges. ${ }^{6}$ Because Sager does not think constitutional interpreters are bound by the Constitution's

1. See, e.g., Ronald DwOrkin, Freedom's Law: The Moral ReAding OF THE AMERICAN CONSTITUTION (1996).

2. $\quad$ See Calder v. Bull, 3 U.S. (3 Dall.) 386, 387-88 (1798) (Chase, J.).

3. See id.

4. See DAVID A.J. Richards, Foundations of AMERICAN CONSTITUTIONALISM 13 (1989) (citing JOHN RAWLS, A THEORY Of JustiCE 195-257 (1999)); see also DAvid A.J. RICHARDS, TOLERATION AND THE CONSTITUTION 41 (1986) (citing the same).

5. See Frank I. Michelman, The Supreme Court, 1968 Term-Foreword: On Protecting the Poor Through the Fourteenth Amendment, 83 HARV. L. REV. 7, 14-15 (1969).

6. See Lawrence G. Sager, Justice in Plainclothes: A Theory of American Constitutional Practice 71-72, 76, 82-83 (2004). 
original meaning, ${ }^{7}$ it is not clear to me on his view what prevents the Constitution from achieving justice rather than merely seeking it.

Ronald Dworkin merits special attention as a constitutional moralist of the left. Sometimes Dworkin supports constitutional leftism through his general interpretive theory of law, including constitutional law. ${ }^{8}$ For Dworkin, the law of a community is determined by asking what are the most morally acceptable principles that fit a sizeable fraction of legal materials - the Constitution, statutes, administrative rules, court decisions, and so on. ${ }^{9}$ Indeed, even the content of those legal materials is not fixed but is itself interpreted by reference to moral principles. ${ }^{10}$ I have criticized Dworkin's theory in depth elsewhere and will not repeat those criticisms. ${ }^{11}$ All I wish to point out here is that Dworkin's general approach to law allows him to "find" his favored moral principles in the Constitution.

At other times, however, Dworkin gets to his liberal principles of constitutional law by a more conventional route, one that does not rely on his general theory of law. Instead, like some of the other moralists, he claims that those principles accord with the semantic intentions of the Framers and are nothing more than what was the semantic meaning of specific provisions of the Constitution. ${ }^{12}$

7. See id. at 30, 35, 42-69.

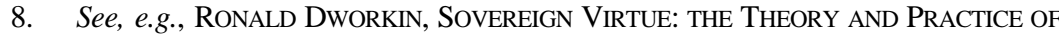
EQUALITY 370-71 (2000).

9. See RONALD DWORKIN, LAW’s EMPIRE 355-99 (1986).

10. See id. at 225-75.

11. These criticisms are found in Larry Alexander \& Ken Kress, Against Legal Principles, in LAW AND InTERPRETATION: EsSAYS IN LEgAL PHILOSOPHY 279 (Andrei Marmor ed., 1995) and Lawrence Alexander \& Michael Bayles, Hercules or Proteus? The Many Theses of Ronald Dworkin, 5 Soc. ThEORY \& PrAC. 267 (1980). These criticisms include: Dworkin never makes clear how one is to fix the legal content for purposes of "fit," given that the "law" is itself the product of fit and acceptability; Dworkin gives no convincing rationale for the diachronic equality that he claims underlies the fit requirement and that in theory should apply to legislatures as well as courts-and furthering diachronic equality, in contrast to taking account of reliance interests, is perverse and untenable; moral acceptability will dictate the morally proper level of fit and will not give effect to past moral errors except insofar as they have created reliance interests; and on Dworkin's theory, legislation may fail to change the "law" in the way the legislature intended, despite what most of us believe.

12. See Ronald Dworkin, Comment, in A MATTER OF INTERPRETATION: FEDERAL COURTS AND THE LAW 115, 119, 122 (Amy Gutmann ed., 1997). 
Those theorists—-Richards, Michelman, Sager, and Dworkin-represent the moralists of the left. ${ }^{13}$ There are, however, moralists of the right. The latter see the Constitution as an attempt to implement the natural law-a natural law of a distinctly conservative or libertarian hue.

One such moralist of the right is Hadley Arkes. Arkes argues that, in interpreting the Constitution, one must go beyond its text to first principles - principles that are antecedent to it. ${ }^{14}$ And although he would strenuously resist being labeled as on the right, because his moral views are implicitly libertarian, ${ }^{15}$ and because he believes all law, including constitutional law, must be interpreted to accord with moral reality, ${ }^{16} \mathrm{I}$ shall put my good friend, Michael Moore, perhaps much to his chagrin, into the camp of constitutional moralists who are at least somewhat on the right.

\section{THE POLITICAL THEORISTS}

My next category of constitutional theorists contains those who "interpret" the Constitution as the implementation of a political theory. Now I realize that hiving off the political theorists from the moralists is

13. I should also mention as moral theorists of the left in constitutional theory James Fleming and Sotirios Barber, whose approaches and conclusions closely resemble those of Dworkin. See generally SotiRIOS A. BARBER \& JAMES E. Fleming, CONSTITUTIONAL INTERPRETATION: THE BASIC QUESTIONS 155-70, 189-92 (2007) (describing competing philosophical approaches to constitutional interpretation and focusing on Dworkin's fusion of constitutional law and moral philosophy).

14. See, e.g., HAdLEy ARKes, BEyond the CONSTITUTION 10-11, 16-17 (1990).

15. I say this because Moore believes duties to aid are much weaker than duties not to harm, a view that has libertarian implications. See, e.g., Michael S. Moore, Causation and Responsibility: An Essay in LaW, Morals, and Metaphysics 55-56 (2009).

16. See, for example, Moore's view of constitutional interpretation in MichaEL S. Moore, EducAting OnEself in Public 439-42 (2000). Moore's natural law theory of interpretation is complex because he realizes there is a moral value served by interpreting legal texts as ordinary communications and opaque to whatever moral values those communications might serve or disserve. Nevertheless, he compromises that opacity and allows some adjustment between treating the text as an ordinary communication and as merely a conduit to correct moral values. I view the relation between the authorial meaning of a legal text and the correct moral values any such text is meant to serve as presenting an irresolvable practical dilemma. As I have put it in several pieces, there is an inevitable "gap" between the content of morally desirable legal rules and the moral desirability of the actions or forbearances those rules command. That gap is elaborated and explored most fully in LARRY Alexander \& EMily SHerwin, THE Rule of Rules 53-95 (2001). Moore's approach either fails to eliminate that gap or else collapses legal texts, including the Constitution, into morality, thus rendering the texts themselves irrelevant. 
somewhat arbitrary, given that the former generally put forward their political theory in service of a moral theory. Indeed, David Richards, whom I have labeled a moralist, refers to his views as political theory. ${ }^{17}$ Still, as a matter of emphasis at least, the political rather than the moral theory is dominant in the political theorists' approach to the Constitution.

My two leading exemplars here are John Ely and Richard Epstein. Ely famously reads the Constitution as a whole and almost all of its clauses as in service of "representation-reinforcement." 18 Therefore, he argues, constitutional interpretation should further that political value. ${ }^{19}$ In the background is basically a moral theory of preference-satisfaction utilitarianism; but it is the political value of representation-reinforcement, not the morality of utilitarianism, that does the constitutional work in Ely's theory.

Richard Epstein also reads the Constitution through a political lens. For example, in his book Takings, he argues for a very broad interpretation of the takings clause ${ }^{20}$ to prevent wealth-diminishing rent-seeking. ${ }^{21}$ And in a number of other works on constitutional law, Epstein's major concern is to interpret constitutional law so as to prevent wealth-diminishing political policies. ${ }^{22}$ Although Epstein's prescriptions will generally be congenial to Lockean libertarians, his ultimate moral justification for his constitutional prescriptions is a utilitarian one. ${ }^{23}$ As with Ely, however, Epstein's political theory, not his moral one, is what is prominent in his approach to the Constitution.

Ely and Epstein read their political theories into the Constitution as a whole. Others read certain clauses through the lens of political theory. For example, Don Regan would read the commerce clause ${ }^{24}$ as implementing the political theory of subsidiarity-the theory that holds

17. See supra text accompanying note 4.

18. See JoHn Hart Ely, DEMOCRACY AND Distrust (1980).

19. See id.

20. U.S. CONST. amend. V.

21. See Richard A. Epstein, Takings: Private Property and the Power of EMINENT DOMAIN (1985) (discussing the conflict between citizens' private rights to own property and the state's power to take property coercively).

22. This is a common Epstein theme running from his 1985 book on takings through his most recent book, RiCHARD A. EPSTEIN, THE CLASSICAL LIBERAL CONSTITUTION: THE UNCERTAIN QUEST FOR LIMITED GOVERNMENT (2014).

23. See EPSTEIN, supra note 21, at 5.

24. U.S. Const. art. I, § 8, cl. 3. 
that regulation should be implemented by the lowest level of government that can avoid spillovers and collective action problems. ${ }^{25}$ A similar approach to that clause has been advocated by Robert Cooter and Neil Seigel. ${ }^{26}$ Neither Regan nor Cooter and Siegel claim that their political principle is how the authors of the commerce clause intended the clause to be interpreted. ${ }^{27}$ Rather, as with Ely and Epstein, they argue for reading their political theory into the clause rather than drawing it out of the clause.

At this point, lest I be misunderstood, I should emphasize that none of my moralists or political theorists completely ignore the actual Constitution. Nor would they admit that they were not interpreting it. Rather, they would claim that underlying the Constitution, or at least certain of its clauses, are certain moral and political truths and that the Constitution was an attempt by fallible human beings to realize those truths. They are, they would say, faithfully interpreting the Constitution by resorting to the more abstract intentions of the Constitution's authors rather than their more concrete ones. They are interpreting those authorial intentions at a high level of generality and translating them in light of what is morally, politically, and factually true.

Notice, however, that at the highest level of generality, constitutional authors want to do what is right, just, and most conducive to good government. The moralist and political theorist interpreters can therefore always claim that they, the interpreters, are, in implementing their favorite moral or political theories, doing what the constitutional authors wanted them to do, however much the theories of the interpreters are at odds with the constitutional authors' beliefs and more specific constitutional intentions. Constitutional fidelity in interpretation comes easily-I would say far too easily - if one ascends to the highest level of generality of the constitutional authors' intentions.

25. Donald H. Regan, How To Think About the Federal Commerce Power and Incidentally Rewrite United States v. Lopez, 94 MicH. L. REV. 554, 555-58 (1995).

26. Robert D. Cooter \& Neil S. Siegel, Collective Action Federalism: A General Theory of Article I, Section 8, 63 STAN. L. REV. 115, 117-19 (2010).

27. See Cooter \& Siegel, supra note 26, at 120; Regan, supra note 25, at 556-57. 


\section{THE JURISTOCRATIC AND LIVING CONSTITUTION THEORISTS}

My next category of theorists includes those who put judicial decision making at the center of constitutional law. The most notable contemporary academic advocate of constitutional juristocracy is David Strauss. Strauss is a proponent of "living constitutionalism," in which judges develop constitutional doctrine in common law fashion. 28 The Constitution itself-or, not to beg any questions, the text of the Constitution - is fully present only at the outset of the development of constitutional law. ${ }^{29}$ From there, development takes place the way common law development takes place-through precedents building upon precedents. ${ }^{30}$ Constitutional law becomes judge-made law, not law made by those who drafted and ratified the document in the National Archives. ${ }^{31}$

Strauss's common law constitutionalism surely has a number of proponents in the academy and practitioners in the courts, including the Supreme Court. $^{32}$ Moreover, Strauss denies that this approach throws the Constitution aside. Like some of the moralists and political theorists who find warrant for pushing their values as constitutional law, Strauss argues that common law constitutionalism is really what the constitutional authors had in mind in certain constitutional clauses, such as those referring to equal protection, due process, and freedom of speech. ${ }^{33}$ The constitutional authors expected judges to keep up with the times and its demands rather than to preserve in amber the authors' own gloss on those clauses, or so Strauss argues. ${ }^{34}$ What differentiates Strauss's view of these clauses from the moralists' and political theorists' views of them is that

28. See generally David A. Strauss, The Living Constitution (2010) (developing and applying the concept of a living constitution through developments in the common law).

29. See id. at 33.

30. See id. at 3, 35.

31. See id. at 34-35.

32. See, e.g., id. at 53-54 (discussing the Supreme Court's application of common law constitutionalism in the context of the First Amendment); see also Abigail R. Moncrieff, Common-Law Constitutionalism, the Constitutional Common Law, and the Validity of the Individual Mandate, 92 B.U. L. REV. 1245, 1246 (2012) (critiquing Strauss's common law constitution philosophy).

33. See STRAUSS, supra note 28, at 112-14.

34. See id. 
Strauss does not see them as invitations to do moral or political theoryalthough, of course, at some level Strauss is doing that himself.

A related view, but one that places less emphasis on judges, is Jack Balkin's "living originalism." because he believes it is faithful to the original meanings of the Constitution's provisions. ${ }^{36}$ Some of those provisions, however-much the same ones that Strauss invokes - state broad principles, the content of which is contested and contestable. ${ }^{37}$ And like Strauss, Balkin does not claim that these principles should, as a matter of their meaning, be elaborated as his own moral views would dictate. ${ }^{38}$ Unlike Strauss, however, Balkin does not make judges the central actors in the drama of these principles' elaboration. ${ }^{39}$ Rather, he sees social movements and political contests as the crucibles in which their meanings are fleshed out. ${ }^{40}$ The courts then ratify those meanings in their constitutional decisions. ${ }^{41}$ But social movements and politics are the major engines of constitutional development, not judges. ${ }^{42}$

\section{THE PRACTICE THEORISTS}

My next group of constitutional theorists includes those who view constitutional law as what we do when we do constitutional law. In other words, in their view, constitutional law is entirely self-referential.

The most influential proponent of such a view is Philip Bobbitt. ${ }^{43}$ Bobbitt claims that there are six modalities of constitutional argument-historical, textual, structural, prudential, doctrinal, and ethical—and that although

35. See generally JACK M. BALKIN, LIVING ORIGINALISM (2011) (presenting Balkin’s view that an originalist interpretation of the Constitution and the flexibility to adapt to changing public values are compatible).

36. Id. at 3.

37. Id. at 232.

38. See id. at 256.

39. See id. at 279.

40. See id. at 81-89.

41. See id. at 89-93.

42. See generally 1 Bruce AcKerman, We the People: Foundations (1991). Balkin distinguishes his living constitutionalism from Bruce Ackerman's theory of constitutional change. Balkin correctly sees Ackerman's notion of constitutional moments as an account of constitutional revolutions rather than as an account of changing meanings given an unchanged Constitution. See BALKIN, supra note 35, at 309-12.

43. Bobbitt develops his views in two books: PhILIP BoBBitT, CONSTITUTIONAL FATE: THEORY OF THE CONSTITUTION (1982) [hereinafter BoBBitT, CONSTITUTIONAL FATE]; Philip Bobbitt, Constitutional Interpretation (1991) [hereinafter BobBitT, CONSTITUTIONAL INTERPRETATION]. 
these overlap, they are distinct. ${ }^{44}$ None can be reduced to another. ${ }^{45}$ Moreover, they are not related hierarchically, with some modalities lexically superior to others. ${ }^{46}$

I have argued elsewhere that the modalities view of constitutional law is a nest of confusions. ${ }^{47}$ As I put it, the fact that lawyers argue for a specific outcome by invoking whichever modality favors their position does not mean the Constitution is nothing but the argumentative practice of invoking these modalities. ${ }^{48}$ When lawyers invoke history, text, structure, prudence, doctrine, or ethics, they are claiming the factor they are invoking, not their practice of invoking it, is the law. ${ }^{49}$

Second, the Constitution cannot be all of these modalities simultaneously. ${ }^{50}$ Indeed, unless the modalities were lexically ordered, so that, for example, original meaning trumped precedent-doctrine-or vice versa, the Constitution could only be one of them. ${ }^{51}$ That is because they cannot be coherently combined..$^{52}$ Trying to combine original meaning with precedent and with justice would be, as I put it, like "combining" $p i$, green, and the Civil War. ${ }^{53}$

Given their nonlexical relationship with each other and their inability to be combined, when two lawyers invoke different modalities in a constitutional case, they are either arguing past each other rather than with each other, or else they are asking the court to choose their favored modality, at least for this case. ${ }^{54}$ I say "at least for this case" because the modalities are supposed to persist even if they failed to prevail in various cases. $^{55}$

44. See Bobbitt, Constitutional Fate, supra note 43, at 8; BobBitt, CONSTITUTIONAL INTERPRETATION, supra note 43, at 12-22.

45. See BOBBITT, CONSTITUTIONAL INTERPRETATION, supra note 43, at 22.

46. See BoBbitT, Constitutional FATE, supra note 43, at 8.

47. Larry Alexander, Telepathic Law, 27 Const. Comment. 139, 146 (2010). This paragraph and the following three paragraphs are a close paraphrase of pages 146 and 147 from Telepathic Law.
48. Id.
49. Id.
50. Id.
51. Id.
52. Id.
53. Id.
54. Id. at $146-47$
55. Id. at 147. 
In truth, each modality represents a different Constitution. ${ }^{56}$ In the historical modality, the Constitution is that set of norms intended by the historical Constitution's authors. ${ }^{57}$ In the doctrinal modality, the Constitution is that set of norms established by Supreme Court precedents. ${ }^{58}$ In the ethical modality, the Constitution is the set of norms the interpreter believes are morally best. ${ }^{59}$ Because these modalities cannot be meaningfully combined, and because it strains credulity that when advocates employ a modality they are asking the court to choose a Constitution for this case only, the modalities view of constitutional theory collapses. ${ }^{60}$

The other practice theory of note is that of Mitch Berman. Berman argues that law in general, including constitutional law, is an "argumentative practice." 61 Berman claims that legal decisions can rest, not on the truth about some preexisting norm or on mere choice, but on the better argument. ${ }^{62}$ Because legal arguments invoke quite disparate considerations-considerations that are incommensurable-decisions responding to such arguments cannot be responding to some metaphysical truth but to a sense of which arguments are weightier or more reasonable. ${ }^{63}$ And that sense will be born of participating in the practice of legal argumentation.

\footnotetext{
56. Id.

57. Id.

58. Id.

59. Id.

60. Id. As I stated in Telepathic Law,

My suspicion is that the appearance of several modalities is produced for the following reasons. First, the original meaning and erroneous judicial accounts of that original meaning that are embodied in precedents create two conflicting sources of legal authority. Second, considerations of justice cannot, as I have said, be combined with original meaning or precedent. Nor can justice compete with original meaning given that the purpose of having authoritative legal texts and tribunals is to settle authoritatively what justice requires. At most, considerations of justice can be invoked when an authoritative standard needs to be given content, or invoked as evidence of original meaning. All the other modalities mentioned by Bobbitt and others can, I believe, be shown to be derivative of original meaning or precedent.

61. Mitchell N. Berman, Constitutional Theory and the Rule of Recognition: Toward a Fourth Theory of Law, in THE Rule OF RECOGNITION AND THE U.S. CONSTITUTION 269, 285 (Matthew D. Adler \& Kenneth Einar Himma eds., 2009).

62. See id. at 288.

63. See id. at 288-89.
} Id. 
Without an ontological account of the Constitution and its norms, one that is external to the practice of legal argumentation, how can we tell if a constitutional argument is weighty or reasonable? In another piece, Berman argues that we do so by a method of "reflective equilibrium" in which we consult our constitutional intuitions as well as the Constitution's text, precedent, and so forth. ${ }^{64}$

Berman gives as an example of how his methodology might work the controversy over whether John McCain was ineligible to become President because of the Constitution's requirement that the President be a "natural born citizen." 65 McCain had been born to American parents in the Panama Canal Zone, then a U.S. territory. ${ }^{66}$ The meaning of natural born citizen and thus whether it includes citizens like McCain has never been authoritatively resolved. ${ }^{67}$ Berman argues that despite this, most legal practitioners had a strong "conviction" that McCain was constitutionally eligible and that their conviction was not contingent on the original meaning of the clause. ${ }^{68}$ That conviction, Berman claims, is a datum for reflective equilibrium, and it might prevail over other data, such as the original meaning and precedent. ${ }^{69}$

I confess I do not understand Berman's notion of intuitions or convictions about what the law, including the Constitution, requires. Of course, I have convictions about what good laws would require. And my familiarity with history and culture allows me to predict what a particular country's constitution probably contains. But on matters like the natural born citizen clause, although I have a conviction about which of its possible meanings would be best as a matter of policy, and a prediction regarding what the authors of the Constitution most likely meant by it, I would surely not deem the former to be the clause's meaning, nor would the latter withstand strong evidence to the contrary.

64. Mitchell N. Berman, Reflective Equilibrium and Constitutional Method: Lessons from John McCain and the Natural-Born Citizenship Clause, in THE CHALLENGE OF ORIGINALISM: THEORIES OF CONSTITUTIONAL INTERPRETATION 246, 258-60 (Grant Huscroft \& Bradley W. Miller eds., 2011).

65. Id. at 261-73. The natural born citizen clause of the Constitution states, "No person except a natural born citizen . . . shall be eligible to the Office of President ...." U.S. CONST. art. II, § 1, cl. 5.

66. Berman, supra note 64 , at 261.

67. Id. at 262.

68. Id. at 248

69. See id. at 267-69, 273-74. 
Here is how I put my objection to Berman's reflective equilibrium approach in earlier pieces:

With respect to reflective equilibrium, which I agree is an appropriate methodology for determining one's moral views, that method is completely inappropriate when it comes to the content of specific posited stuff and to other specific facts. Did or did not the framers put the specific language regarding "natural born Citizen" in Article II? That question-to which the answer is "yes"-is not resolved by reflective equilibrium any more than is the question how high in feet is New Zealand's Mt. Cook. Or if reflective equilibrium does apply to these questions because we must achieve coherence among all of our empirical beliefs-our beliefs about whether there is a natural born citizen clause in the Constitution and the height of Mt. Cook must cohere with our beliefs about the trustworthiness of our eyesight, of geographers' measuring devices, of those who print legal materials, of encyclopedias' renditions of others' reports, and so on-then the objection to applying reflective equilibrium as Berman does devolves into a denial that we have case-specific constitutional or, more generally, legal intuitions of the type on which Berman relies.

Berman asserts that without knowing the intended meaning of "natural born Citizen" in Article II, we can have confident intuitions that John McCain was constitutionally eligible to be President, despite his birth in the Panama Canal Zone to U.S. citizens, and that President Warren Harding was likewise constitutionally eligible, despite his having been born by Caesarian section. I deny, however, that one does or can have constitutional or legal intuitions that pre-exist and provide the grist for building our theory of legal interpretation. Take away the texts of posited law, which, as I have said, are nothing other than the media by which legal authorities' intended meanings are conveyed, and we have no case-specific legal intuitions at all. Of course, we might have some general sense of what reasonable and just laws would look like, and we might assume that most laws-in western democracies at least, if not in North Korea - would be relatively reasonable and just. Thus, we might, in the absence of the texts, have decent surmises about the general content of the laws. But I doubt that we have any case-specific intuitions about whether "titles of nobility" are constitutionally outlawed; whether states can issue "letters of marque and reprisal;" the date on which presidential elections must be held; whether one state can split into two or more; when recess appointments expire; or countless other matters that the constitutional authors address - much less the length of the statute of limitations for fraud in Alabama. ${ }^{70}$

70. Larry Alexander, Simple-Minded Originalism, in The Challenge of ORIGINALISM: THEORIES OF CONSTITUTIONAL INTERPRETATION, supra note 64, at 87, 9798 (footnotes omitted). Reflective equilibrium in moral epistemology imposes no priori restrictions on our ability to modify our case-specific intuitions in light of more general principles and vice versa. In legal reasoning, however, some data points — specific texts—are unalterable. Reflective equilibrium cannot operate as it does in moral reasoning and therefore the practice theories cannot appropriate its epistemological credentials in their behalf. See Jeremy Waldron, Do Judges Reason Morally?, in EXPOUNDING THE CONSTITUTION: EsSAYS In CONSTITUTIONAL THEORY 38, 52-53 (Grant Huscroft ed., 2008). 
My hunch is that the legal intuitions argument gets whatever force it has in cases where the original meaning is unclear and where we think considerations of policy or justice strongly favor one possible meaning over the other. That explains whatever force Berman's examples have. On the other hand, where the mistakenly assumed original meaning is viewed as neutral or as undesirable, the "legal intuition" view has no purchase. Most people, for example, probably wish that the Fourteenth Amendment had not granted birthright U.S. citizenship to the children of aliens temporarily or illegally in the country. No other country does this, and there are no good reasons to do it. Still, almost everyone assumes and has assumed for a long time that the Fourteenth Amendment dictates this result. If we now become convinced by scholars ... that this interpretation is erroneous ... would we still want to say that the new interpretation was not the law? I think not. ${ }^{71}$

Let me conclude this section with a final verdict on the constitutional law as an argumentative practice view of which Bobbitt and Berman are principal proponents: I find the view to be deeply incoherent. Either our arguments about the Constitution have an external object or they do not. If the latter and they are self-referential, then they are self-undermining, for we cannot sensibly argue about whether we are arguing.

The view that the Constitution is an "argumentative practice" represents a category mistake. ${ }^{72}$ It substitutes an external point of view that an observer of constitutional arguments might hold-namely, that constitutional law appears to be a series of never-ending arguments-for the internal point of view of those engaged in the arguments. ${ }^{73}$ Argument over the Constitution's meaning does not show that the meaning is itself an argumentative practice any more than arguments among physicists about the number of dimensions of the universe or the nature of elementary particles showed that the dimensions of the universe and the nature of elementary particles are themselves argumentative practices. ${ }^{74}$ From the internal point of view of the participants in constitutional arguments, the Constitution and its meaning are external to their arguments - they are what those arguments are about. ${ }^{75}$

71. Alexander, supra note 47, at 149-50 (footnotes omitted).

72. Alexander, supra note 70 , at 95 .

73. Id.

74. Id.

75. Id. 


\section{THE ANTICONSTITUTIONALISTS}

I have labeled my next group of constitutional theorists "anticonstitutionalists" because they wish to demote the Constitution's status and importance. They are particularly hostile to judicial review and especially to the judicial supremacy view of Cooper v. Aaron. ${ }^{76}$

Mark Tushnet falls into this category. In 1999, he published Taking the Constitution Away from the Courts, the principal theses of which are a rejection of judicial supremacy and the advocacy of the "thin" Constitution rather than the "thick" one. ${ }^{77}$ The latter is the actual Constitution in all its detail. ${ }^{78}$ The former consists of basic principles, such as equality, freedom of expression, and liberty. ${ }^{79}$ Tushnet argues that judicial supremacy is neither necessary nor desirable on behalf of the thin Constitution. ${ }^{80}$ Legislative action, which Tushnet calls "populist constitutional law," is where the thin Constitution is best secured. ${ }^{81}$ And because legislative action cannot be entrenched against reversal by subsequent legislative action, the Constitution on Tushnet's view will turn out to be "fundamental law" and supreme over ordinary law only, if at all, in the minds of the citizenry and their legislative representatives. ${ }^{82}$

Another anticonstitutionalist is Louis Michael Seidman, Tushnet's long-time colleague and occasional coauthor. ${ }^{83}$ Seidman's book, Our Unsettled Constitution, makes a case against settling fundamental matters in a Constitution. ${ }^{84}$ Seidman's point is that any such settlement will appear erroneous to some people at some point, and they will contest its legitimacy, especially if democratic contestation of that settlement is foreclosed by

76. 358 U.S. 1 (1958)

77. Mark Tushnet, TAKing the CONSTitution Away from the COURTS 7, 9-14 (1999).

78. Id. at 9

79. Id. at 11.

80. See id.

81. See id. at 12 .

82. See id. at 13-14. Interestingly, many believe that judicial review is most necessary for matters arising under the thick Constitution, especially those matters that determine the rules under which ordinary politics is conducted, such as how Congress and the President are chosen, how a bill becomes law, who can make a treaty or appoint executive officers, and so on. Major disputes over these matters, although they might be handled satisfactorily without the intervention of the courts as neutral arbiters, might not be, with the consequence that politics might devolve into anarchy.

83. See, e.g., Louis Michael Seidman \& MARK V. Tushnet, Remnants of BELIEF: CONTEMPORARY CONSTITUTIONAL ISSUES (1996).

84. See louis Michael Seidman, Our Unsettled Constitution: A New Defense of CONSTITUTIONALISM AND JUDICIAL REVIEW 54-55 (2001). 
strong-form judicial review of the Cooper v. Aaron kind. ${ }^{85}$ I believe that at its deepest level, Seidman's worry is a worry about whether not only constitutional law, but any law, can be viewed as normative by those who disagree with its content - which is the only time the normativity of law matters. ${ }^{86}$

A recent prominent entrant in the list of anticonstitutionalists is Larry Kramer. Kramer calls his position "popular constitutionalism” because he, like Tushnet and Seidman, opposes judicial supremacy and supports vesting "the people" with ultimate authority over constitutional interpretation. ${ }^{87}$ Kramer is vague about the interpretive methodology the people should employ. ${ }^{88}$ He is clear, however, that constitutional law is not ordinary law of a higher rank, something the Constitution itself seems to imply. ${ }^{89}$ As he puts it,

Constitutional or fundamental law subsisted as an independent modality, distinct from both politics and from the ordinary law interpreted and enforced by courts. It was a special category of law. It possessed critical attributes of ordinary law: its obligations were meant to be binding, for example, and its content was not a matter of mere will or policy but reflected rules whose meaning was determined by argument based on precedent, analogy, and principle. Yet constitutional law also purported to govern the sovereign itself, thus generating controversies that were inherently matters for resolution in a political domain. Modern discourse has so thoroughly conflated the meaning of "constitution" with "law" and of "law" with "courts" that we no longer possess the language to describe a distinct category of this sort; the best way to capture its essence today may thus be (as one leading historian has done) to call it "political-legal.",90

My final anticonstitutionalist is Jeremy Waldron. Like the others, Waldron is a fierce opponent of strong judicial review, but unlike Kramer, who reposes constitutional interpretation vaguely in "the people," Waldron argues specifically for legislative supremacy in constitutional law. ${ }^{91}$ The

85. See id. at 55.

86. I shall return to this topic at the conclusion of my lecture.

87. See Larry D. Kramer, The People Themselves: Popular Constitutionalism AND JUDICIAL REVIEW 24-25, 28-32 (2004).

88. See Larry Alexander \& Lawrence B. Solum, Popular? Constitutionalism?, 118 HARV. L. REV. 1594, 1603, 1621-26 (2005) (reviewing KRAMER, supra note 87).

89. U.S. CONST. art. VI, cl. 2 ("This Constitution ... shall be the supreme Law of the Land ....”).

90. KRAMER, supra note 87, at 24 (footnotes omitted).

91. See Jeremy Waldron, The Core of the Case Against Judicial Review, 115 YaLE L.J. 1346, 1353, 1387-88 (2006). 
underlying value motivating Waldron is that of equality, which for him extends to equality of say over the meaning of constitutional principles. ${ }^{92}$

What unites the anticonstitutionalists is their hostility to strong judicial review and to viewing the 1789 Constitution and its amendments as ordinary law, fit for ordinary legal analysis and craft. Judges are adept at the latter. If, however, the Constitution is not merely ordinary law of the highest rank, but not ordinary law at all, then its meaning is not necessarily within the special ken of lawyers and judges. As best I can tell, the anticonstitutionalists regard the Constitution as the name we give to the locus of political clashes over our most fundamental ideals rather than a legal document produced by specific people at a specific time.

\section{THE ORIGINALISTS}

My final category of constitutional theorists is that of the originalists. Originalists regard the Constitution as an historical artifact, a legal document posited by certain people following certain procedures at specific times. $^{93}$ For originalists, the Constitution is just a super statute enacted in a particular way. Apart from its supremacy over other law, the Constitution is just ordinary law and should be interpreted as if it were ordinary law. ${ }^{94}$

Originalists divide into two camps with respect to how that interpretation should proceed. They agree that the meaning of a constitutional provision is fixed at the time the provision is enacted and is unchanging thereafter. They disagree, however, about what that meaning is. A few, including me, believe that the meaning of a constitutional provision is its authorially intended meaning. The majority of originalists believe that a provision's meaning is its "original public meaning." 95 For short, I shall designate the first view, the one I hold, as the originally-intended meaning view or "OIM." I shall designate the original public meaning view as "OPM."

Those of us in the OIM camp view the positing of law, including constitutional law, as the communication of norms chosen by those with authority to choose them to those who will be subject to them. The authors' intention in the communication is to produce in their audience the uptake

92. See Jeremy Waldron, Precommitment and Disagreement, in CONSTITUTIONALISM: PhiLOSOPHICAL Foundations 271, 280-81 (Larry Alexander ed., 1998).

93. See, e.g., Larry Alexander, The Method of Text and ?: Jack Balkin's Originalism with No Regrets, 2012 U. ILL. L. REV. 611.

94. See id. at 612.

95. See Alexander, supra note 70, at 89. 
that corresponds to the authors' intended meaning. And the audience's task is to ascertain the meaning that the authors intended. On this view, posited law, including the Constitution, is just ordinary communication applied to the communication of legal norms.

Now, there are two real problems that the OIM view must grapple with. One problem is that even the authors themselves may not know whether they intended their norm to cover certain specific applications. The authors of "no vehicles in the park" may be able to answer yes or no to questions such as "Did you intend to cover bicycles?" and "Did you intend to cover ambulances?" but be unable to answer "Did you intend to cover skateboards?" When the authors do not know what meaning they intended, then there is no intended meaning for the audience to discover.

The second problem for the proponents of OIM, one that is oft noted, is that of collective authorship. Whenever the authorities whose intended meanings matter are a group, the question naturally arises whether a group can have an intended meaning. Must all members of the group share the meaning, or at least all members necessary for the norm's enactment?

It was largely in response to this second problem of OIM that most originalists adopted OPM. ${ }^{96}$ For OPM rests not on the meaning intended by a group but on the meaning that a single individual-some representative or idealized member of the public at the time of the enactment of the provision in question-would understand to be the meaning of that provision. ${ }^{97}$

Unfortunately for originalists, if OIM is the frying pan of group intent problems, OPM is a fire of much more formidable ones. First, there is no nonarbitrary way to ascertain or construct the member of the public whose understanding of a constitutional provision is to be determinative. ${ }^{98}$ I have written at length about this problem elsewhere and so shall be brief here. ${ }^{99}$ As I described the problem in a footnote,

\footnotetext{
96. See id.

97. See id.

98. See id. at 89-90.

99. See, e.g., Larry Alexander \& Saikrishna Prakash, "Is That English You're Speaking?” Why Intention Free Interpretation is an Impossibility, 41 SAN DIEGO L. REV. 967, 976 (2004).
} 
... [S] [Sppose we could ask every member of the public in 1791 what he or she believed, say, "freedom of speech" meant. Each member of the public would differ, even if only slightly, in terms of their linguistic facility, their understanding of the general purposes motivating the language of the First Amendment, their familiarity with the debates in Congress and in the state ratifying conventions over the Bill of Rights, and so on. There is no such thing as an "average" of what the members of the public believed the ratifiers meant by "freedom of speech." Nor is there a "median" of such meanings. So one would have to look for the meaning attributed to "freedom of speech" by some "representative" member of the public. But what linguistic facility, familiarity with current events, geographical location, and so on make one a representative member of the public? I do not see any non-arbitrary way of choosing. ${ }^{100}$

Even if we could, contrary to fact, nonarbitrarily construct the member of the public whose interpretation is to be authoritative under OPM-I will call her Mary - why should we care how Mary understood the meaning? After all, Mary herself would not be seeking the OPM-her meaning-but would presumably be seeking the OIM. Moreover, for there to be any space between OIM and OPM, Mary will have to have gotten OIM wrong in certain situations. So why should we follow Mary's erroneous conclusion about OIM rather than our own differing and, as far as we can tell, correct conclusion about OIM? The proponents of OPM have never answered this question.

One worry I have heard voiced by OPM proponents is that the actual authors might have had secret intended meanings that differed from the meanings they expected their audience to receive. ${ }^{101}$ But this worry is completely wrongheaded. One's intended meaning in a communication just is the uptake the speaker intends in his audience. One cannot intend to communicate meaning $\mathrm{X}$ and intend one's audience to have meaning $\mathrm{Y}$ as its uptake.

The second worry I have heard voiced is that it is somehow unfair for people to be governed by norms the actual meaning of which might only become apparent at a later date. Again, this worry is wrongheaded. As I put it elsewhere,

... [S]uppose the authors of the Constitution in saying A intended meaning $X$, but the hypothetical contemporary member of the public would have taken them to have intended meaning Y. It is only later that we come to believe they intended $\mathrm{X}$ by $\mathrm{A}$. Was the public in the interim treated unfairly in assuming $\mathrm{Y}$ rather than X? It is hard to see how. Obviously, if the hypothetical member of the public were ratifying the Constitution, the meaning he was assuming would be important to him. But if he assumed it was $Y$, it would be $Y$, because as a

100. See Alexander, supra note 70, at 89 n.6.

101. See id. 
ratifier, he is the author and is intending $\mathrm{Y}$ as the meaning. If he is not a ratifier, then he has to show that he has been somehow harmed by mistakenly believing the actual authors meant Y rather than X. Although misinterpretations-especially authoritative ones, such as Supreme Court decisions - can induce detrimental reliance, so can misinterpretations of OPM. Detrimental reliance on erroneous interpretations is a problem, but it is not solved by denying that erroneous interpretations are erroneous. ${ }^{102}$

Nor can OPM avoid the collective authorship problem of OIM, the avoidance of which was supposed to be a principal attraction of OPM. For suppose that a provision lacks a single meaning intended by its authors. Rather, there are conflicting intended meanings within the authorial body. But if so, then Mary, our hypothetical member of the contemporaneous public, whose interpretation is supposed to be authoritative under OPM, will herself be unable to interpret the provision. For remember that Mary cannot herself be seeking the OPM. Rather, she must be seeking the OIM. If that fails to provide her with a meaning, she cannot provide a meaning for the rest of us. OPM is ultimately parasitic on OIM.

\section{THE RULE OF RECOGNITION AND THE HARDEST QUESTIONS OF CONSTITUTIONAL THEORY}

It is time, finally, for me to look down upon these conflicting constitutional theories from more Olympian heights. And the first thing to note is that almost every one of these theories could be correct as a theory of our constitutional law. For our constitutional law, like all law, turns on what we, the people, recognize as the ultimate ground of legal authority - what Hart calls the rule of recognition. ${ }^{103}$ And it is possible that the rule of recognition authorizes our institutions to regard, as the supreme law of the land, a particular moral or political theory, the Supreme Court's common law development of fundamental law, fundamental

102. Id. at 90-91 (footnote omitted). Any interpretive theory that posits a meaning that is independent of the interpreter's beliefs about that meaning will entail the possibility that the interpreter will err and thereby rely on the erroneous interpretation in ways that might prove costly if his interpretation is overturned. That might be a reason to refrain from following the correct interpretation where it will prove costly to those who relied on the erroneous one. But it does not show that the erroneous interpretation was not erroneous.

103. See H.L.A. HART, THE CONCEPT OF LAW 97-99 (1961). 
values endorsed by social and political forces, or the authorially intended meanings of the authors of the original Constitution and its amendments. Only the practice theory is ruled out as a logical matter.

But then, what is our rule of recognition? I regard that question as one of the two most difficult questions in legal philosophy. But before I deal with the rule of recognition, let me say something about the other one of the two most difficult questions. That is the question of how it is possible for law to be normative. That question has both an external and an internal dimension. Externally, the question is how can we be obligated to comply with the law when compliance conflicts with the deliverances of our first-order practical reasoning. For if we cannot, then law cannot matter normatively, except insofar as it leads us to predict others' conduct. ${ }^{104}$

Internally, the question is what are we legally bound to do when the institutions that we deem legally authoritative themselves get the law wrong. What if the Supreme Court misinterprets the Constitution? Originalists know this as the problem of nonoriginalist precedents. But the problem arises under any constitutional theory that contains a standard for constitutional correctness other than some institution's ipse dixit.

Back now to the rule of recognition. For Hart, the rule of recognition was whatever criteria officials accepted as determinative of legal validity. ${ }^{105}$ One would think, however, that citizens as well as officials would have to accept those criteria, lest the officials would be nothing more than "gunman writ large" vis-à-vis the citizens. ${ }^{106}$

How then can we tell what rule of recognition the people have accepted? Have, for example, the people accepted the Supreme Court's departures from the originalists' Constitution? They have generally acquiesced in those departures, even ones that they have disliked. But have they been aware that those departures were departures? ${ }^{107}$ Claims, such as those by Ackerman, that the Constitution has been amended

104. For a view that law matters only in this way, see LAURENCE CLAUS, LAW'S EVOLUTION AND HUMAN UNDERSTANDING 46-47, 168 (2012).

105. See HART, supra note 103, at 97-98, 113.

106. After all, Hart regarded it as a flaw in John Austin's theory of law, which viewed laws as a sovereign's commands backed by sanctions, that the theory could not distinguish laws from the threats of gunmen. See id. at 20-25.

107. See Larry Alexander \& Frederick Schauer, Rules of Recognition, Constitutional Controversies, and the Dizzying Dependence of Law on Acceptance, in THE RULE OF RECOGNITION AND THE U.S. CONSTITUTION 175, 189-91. 
outside of the process it prescribes for its own amendment, ${ }^{108}$ to be vindicated must be based on more than mere popular acquiescence and more even than acquiescence plus approval on policy grounds. But how do we test for that and discover what our rule of recognition is? Until we know our rule of recognition, we cannot know the content of our Constitution. But until we know otherwise, I, for one, am betting on the originalists' Constitution.

108. See ACKERMAN, supra note 42, at 41-47; see also Matthew D. Adler, Popular Constitutionalism and the Rule of Recognition: Whose Practices Ground U.S. Law?, 100 Nw. U. L. REV. 719, 720-22, 725 (2006); Frederick Schauer, Amending the Presuppositions of a Constitution, in Responding to IMPERfection: THE THEORY AND PRACTICE OF CONSTitutional AMENDMENT 145, 145 (Sanford Levinson ed., 1995). 
